\title{
Article
}

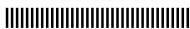

\section{Effect of Fukushima Daiichi Nuclear Power Plant Accident on Lakes in Fukushima Prefecture and Niigata City}

\author{
Naoyuki KANDA, Ying WANG, Noriaki KATAOKA, \\ Ryuta YAMADA, Hiroshi IMAIZUMI ${ }^{\dagger}$ and Naoki KaNO \\ Department of Chemistry and Chemical Engineering, Faculty of Engineering, Niigata University \\ 8050 Ikarashi 2-nocho, Nishi-ku, Nïgata-shi, Niigata Pref. 950-2181, Japan \\ †analysis@eng.niigata-u.ac.jp \\ Received April 20, 2015 \\ Accepted September 8, 2015
}

\begin{abstract}
The Fukushima Daiichi Nuclear Power Plant Accident happened in 12 - 15 th March 2011. This accident caused to the radioactive contamination in the near area. In this work, some lake waters and the sediments were collected in Fukushima Prefecture and Niigata City to clarify the effect of the accident on the area contaminated. As to the collected lake water, an enrichment of "the specific activity of tritium ( $\mathrm{T}$ specific activity)" in each water collected was carried out by the solid polymer electrolyte (SPE) apparatus, and the T specific activity was measured by a liquid scintillation counter. Based on the $\mathrm{T}$ specific activity thus measured, the influence of the accident to the environment was investigated. At the same time, specific activities of radioactive caesiums in the lake sediments were also measured. Consequently, the influence of the Fukushima Daiichi Nuclear Power Plant Accident to the adjacent lakes (e.g., in Fukushima Prefecture and Niigata City) was quantitatively clarified. From the above-mentioned matters, it is found that the effect of the accident on Niigata City is so small, and the accident gradually decreases in Fukishima Prefecture.
\end{abstract}

Key Words : Fukushima Daiichi Nuclear Power Plant Accident, tritium, caesium-137, caesium-134, solid polymer electrolyte apparatus

\section{Introduction}

The accident of the Fukushima Daiichi Nuclear Power Plant occurred in March 2011. This accident caused a level 7 event of the International Nuclear Event Scale that means the worst classification. It is the second scale of the nuclear power plant accident next to Chernobyl disaster. This accident caused a lot of radioactive fallouts, and the fallouts were accumulated not only in near the area but also in the adjacent prefectures. According to our previous research ${ }^{1)}$, Tritium ( $\mathrm{T}$ or $\left.{ }^{3} \mathrm{H}\right)$ specific activity (obtained in Niigata City) was temporary in- creased by the accident. The highest $\mathrm{T}$ content was also found in the first rainfall after the accident ${ }^{2)}$.

As to radioactive fallouts, $\mathrm{T}$ is one of them. Its half-life is 12.32 years, emits $\beta^{-}$ray, and its maximum energy is $18.6 \mathrm{keV}$ (ave. $5.7 \mathrm{keV}$ ). Therefore external exposure from $\mathrm{T}$ can be neglected. However, internal exposure cannot be neglected because $\mathrm{T}$ invades into the body and emits $\beta^{-}$ray to certain cell directly ${ }^{3)}$. In environment, $\mathrm{T}$ behaves with water because most of the chemical form of $\mathrm{T}$ is HTO. Total amount of $\mathrm{T}$ in the world is estimated to be approximately $1300 \mathrm{PBq}(3.5 \mathrm{~kg})$, and this value 


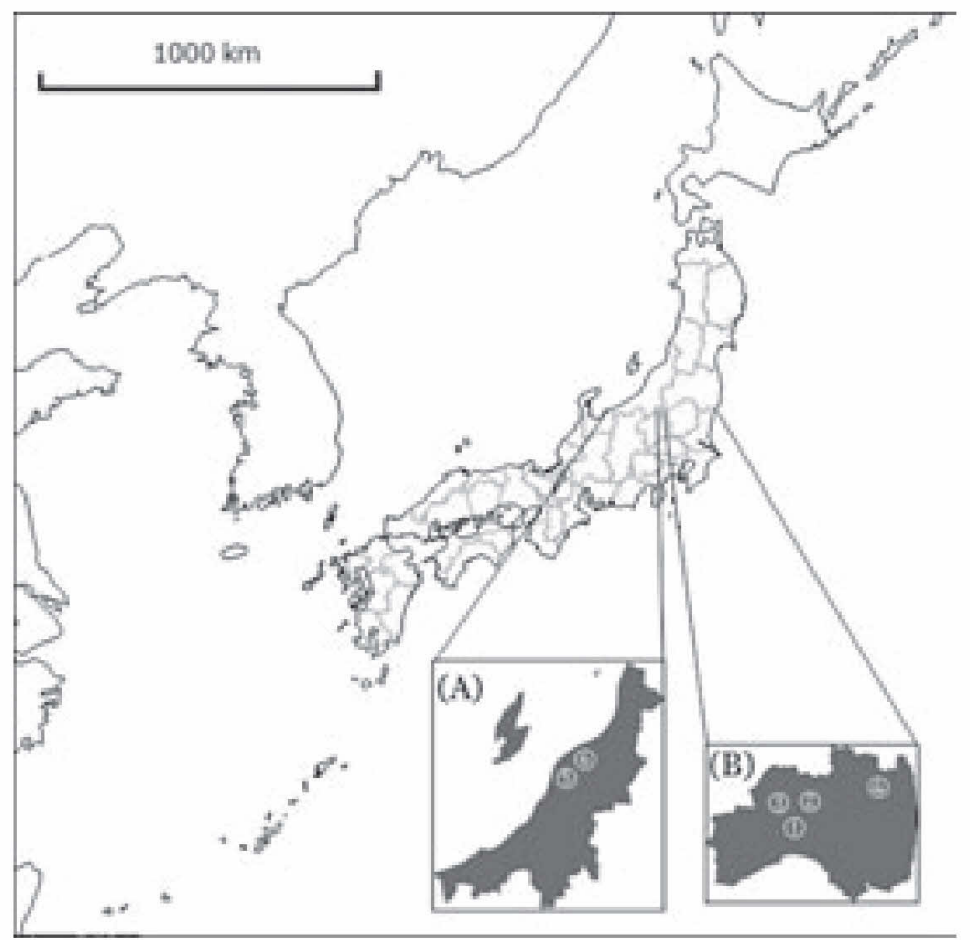

Fig. 1 Locations of Niigata Prefecture(A) and Fukushima Prefecture(B), and of sampling points in (A) and (B).

(A) Niigata Prefecture

(B) Fukushima Prefecture

(1)Lake Inawashiro

(2)Lake Akimoto

(3)Goshikinuma tarn

(4)Lake Hayama

(5)Sakata lagoon

(6)Lake Toyanogata

is similar to the natural equilibrium level ${ }^{4,5)}$. T is naturally produced in the upper atmosphere. When cosmic rays interact with nitrogen nuclei in air ${ }^{6), 7)}$, following (1) occurs, and finally $\mathrm{T}$ decays as (2).

$$
\begin{aligned}
& { }^{14} \mathrm{~N}+\mathrm{n} \rightarrow{ }^{12} \mathrm{C}+\mathrm{T} \\
& \mathrm{T} \rightarrow{ }^{3} \mathrm{He}+\mathrm{e}^{-}+v_{\mathrm{e}}
\end{aligned}
$$

In general, radioactive caesium $\left({ }^{134} \mathrm{Cs}\right.$ and ${ }^{137} \mathrm{Cs}$ ) are not discharged from a nuclear power plant. However, when serious nuclear power plant accident like a Chernobyl Accident is happened, these caesium may be discharged in an environment. The half-life of ${ }^{137} \mathrm{Cs}$ is 30.1 years, and the caesium compounds are generally water-soluble. Thus caesium taken into a body are distributed in whole of the body, and many of them are accumulated into the muscle because it is an alkali metal, and because its physical and chemical properties are similar to those of rubidium and potassium. If a human takes radioactive caesium, about $10 \%$ of them is excreted from the body as sweat and urine. The remaining $90 \%$ ones decrease with a bio- 

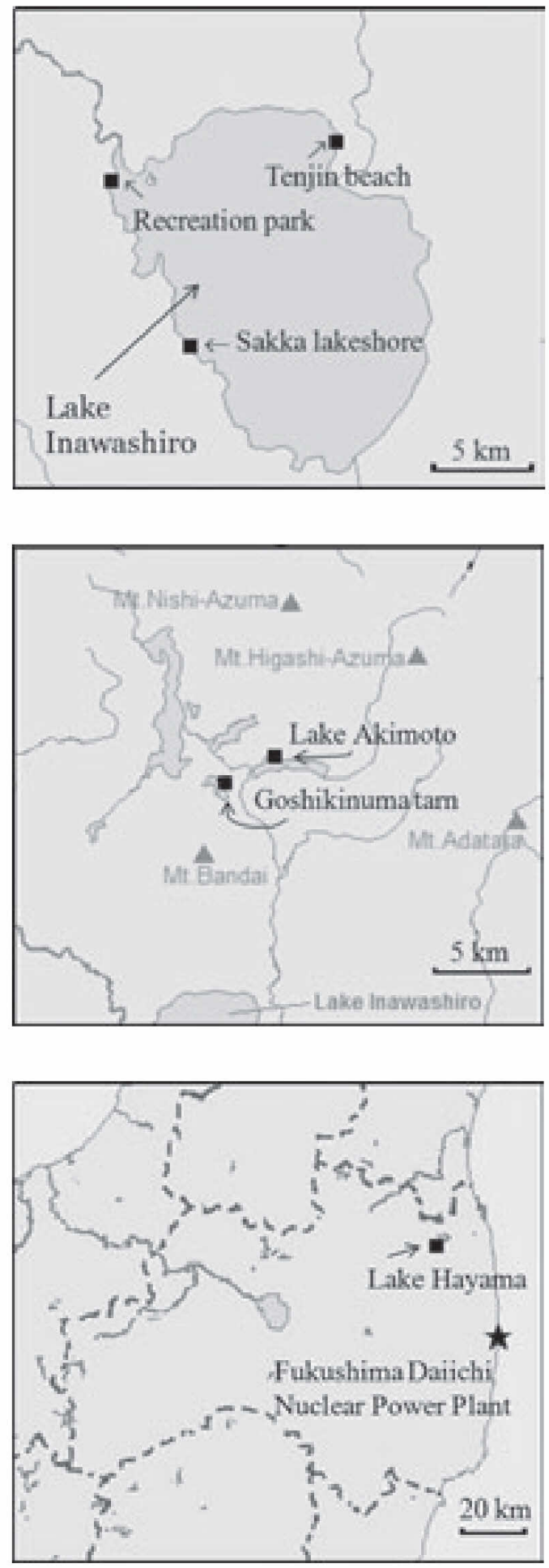

Fig. 2 The sampling points at Lake Inawashiro, Lake Akimoto, Goshikinuma tarn and Lake Hayama in Fukushima Prefecture.

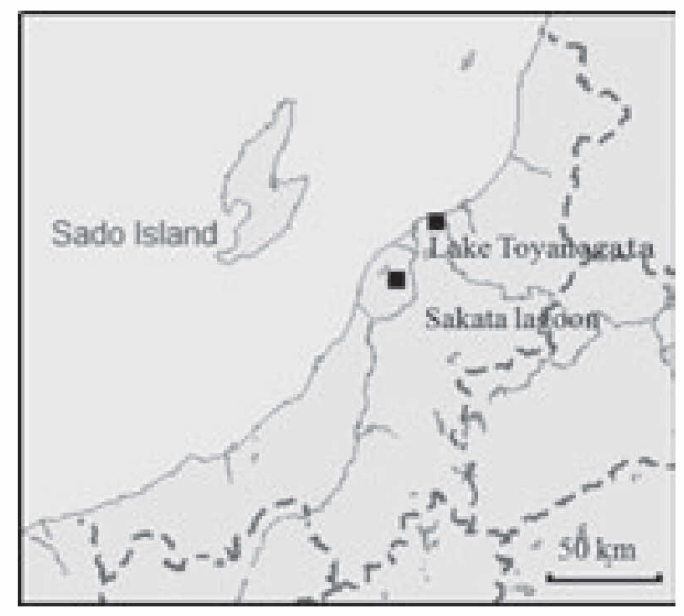

Fig. 3 The sampling points at Lake Toyanogata and Sakata lagoon in Niigata Prefecture.

logical half-life between 50 and 150 days $^{8}$.

Considering the above-mentioned, the following two were aimed in this study: (1) to research the influence of the accident to several lakes in Fukushima Prefecture and to Niigata City, (2) to clarify the effect of the accident on Niigata City.

\section{Experimental}

\section{$2 \cdot 1$ Sampling}

Fukushima Daiichi Nuclear Power Plant locates in Okuma town in Fukushima Prefecture, Japan (Coordinates : $37^{\circ} 25^{\prime} 22.7^{\prime \prime} \mathrm{N} 141^{\circ} 01^{\prime} 58.5^{\prime \prime}$ E). We chose some sampling points in order to research the influence of the accident to some lakes in Fukushima and Niigata. Each location is shown in Fig. 1. There are Lake Inawasiro, Lake Akimoto, Goshikinuma tarn, and Lake Hayama in Fukushima Prefecture shown in Figs. 2. At Lake Inawasiro, we picked up the samples in the three spots(Recreation park, Sakka beach and Tenjin beach). Lake Toyanogata and Sakata lagoon in Niigata City is also shown in Fig. 3. Lake Hayama is the nearest to the Fukushima Daiichi Nuclear Power 
Table 1-1 Several sampling conditions

\begin{tabular}{|c|c|c|c|c|c|c|}
\hline \multirow[b]{2}{*}{ Sampling point } & \multicolumn{3}{|c|}{ 2013.May } & \multicolumn{3}{|c|}{ 2013.Sep } \\
\hline & $\begin{array}{l}\text { distance } \\
\text { from } \\
\text { shore / m }\end{array}$ & $\begin{array}{l}\text { lake water } \\
\text { temperature } \\
/{ }^{\circ} \mathrm{C}\end{array}$ & depth / cm & $\begin{array}{l}\text { distance } \\
\text { from shore } \\
/ \mathrm{m}\end{array}$ & $\begin{array}{l}\text { lake water } \\
\text { temperature } \\
/{ }^{\circ} \mathrm{C}\end{array}$ & depth / cm \\
\hline \multicolumn{7}{|l|}{ Lake Inawashiro } \\
\hline Recreation park & 5 & 16 & 30 & 5 & 21.2 & 10 \\
\hline Sakka beach & 5 & 14 & 30 & 5 & 22.3 & 50 \\
\hline Tenjin beach & 5 & 15.6 & 50 & 5 & 21.7 & 30 \\
\hline Lake Akimoto & 3 & 17 & 10 & 3 & 23.8 & 20 \\
\hline Goshikinuma tarn & 1 & 16 & 10 & 1 & 20.2 & 20 \\
\hline Lake Hayama & 10 & 16 & 30 & 5 & 23.8 & 10 \\
\hline Lake Toyanogata & - & - & - & 1 & 26 & 30 \\
\hline Sakata lagoon & 1 & 23.1 & 20 & 1 & 23.6 & 30 \\
\hline \multicolumn{4}{|c|}{ 2014.May } & \multicolumn{3}{|c|}{ 2014.Oct } \\
\hline Sampling point & $\begin{array}{l}\text { distance } \\
\text { from } \\
\text { shore / } \mathrm{m}\end{array}$ & $\begin{array}{l}\text { lake water } \\
\text { temperature } \\
/{ }^{\circ} \mathrm{C}\end{array}$ & depth / cm & $\begin{array}{l}\text { distance } \\
\text { from shore } \\
/ \mathrm{m}\end{array}$ & $\begin{array}{l}\text { lake water } \\
\text { temperature } \\
/{ }^{\circ} \mathrm{C}\end{array}$ & depth $/ \mathrm{cm}$ \\
\hline \multicolumn{7}{|l|}{ Lake Inawashiro } \\
\hline Recreation park & 5 & 20.6 & 40 & 5 & 25.2 & 20 \\
\hline Sakka beach & 5 & 18.6 & 30 & 5 & 20.9 & 20 \\
\hline Tenjin beach & 5 & 19.4 & 40 & 5 & 21.6 & 30 \\
\hline Lake Akimoto & 3 & 26.2 & 5 & 3 & 21.7 & 10 \\
\hline Goshikinuma tarn & 1 & 20.6 & 10 & 1 & 17.2 & 5 \\
\hline Lake Hayama & 10 & 26.1 & 10 & 10 & 20.6 & 20 \\
\hline Lake Toyanogata & 1 & 29.4 & 15 & 1 & 18.6 & 20 \\
\hline Sakata lagoon & 1 & 22.5 & 50 & 1 & 20.8 & 30 \\
\hline
\end{tabular}

Plant in the sampling points chosen in this work. Sample water and sediment were collected at each lake. The sample water was picked up about 5 meter from beach and depth is roughly 30 centimeter under the surface. The sediment was also picked up using increment scoop (approximately $0-10$ centimeter from the bottom of a lake). We collected these samples in spring and in autumn(in 2013 and 2014). Tables 1-1 and 1-2 show several sampling conditions and geographic coordinates. Dissolved Oxygen(DO), $\mathrm{pH}$ and ORP in the water were immediately measured at each sampling point. As to a reference data, we used the collected precipitation in Niigata City collected every one month. The collecting apparatus was set on a roof of Faculty of Engineering Niigata University ${ }^{9}$. The collected sample is called "Simulated Infiltrating Water", which is similar to grand filtration water ${ }^{10)}$.

\section{$2 \cdot 2$ Sample pretreatment}

As to each collected lake water, an enrichment of $T$ specific activity was carried out by 
Table 1-2 Geographic coordinates sampling points

\begin{tabular}{|c|c|c|c|c|c|c|}
\hline \multirow{2}{*}{$\begin{array}{l}\text { Sampling point } \\
\text { Lake Inawashiro }\end{array}$} & \multicolumn{3}{|c|}{ north latitude } & \multicolumn{3}{|c|}{ east longitude } \\
\hline & & & & & & \\
\hline Recreation park & $37^{\circ}$ & $30^{\prime}$ & $55^{\prime \prime}$ & $140^{\circ}$ & $1^{\prime}$ & $17^{\prime \prime}$ \\
\hline Sakka beach & $37^{\circ}$ & $27^{\prime}$ & $45^{\prime \prime}$ & $140^{\circ}$ & $2^{\prime}$ & $48^{\prime \prime}$ \\
\hline Tenjin beach & $37^{\circ}$ & $31^{\prime}$ & $18^{\prime \prime}$ & $140^{\circ}$ & $6^{\prime}$ & $57^{\prime \prime}$ \\
\hline Lake Akimoto & $37^{\circ}$ & $39^{\prime}$ & $37^{\prime \prime}$ & $140^{\circ}$ & $7^{\prime}$ & $28^{\prime \prime}$ \\
\hline Goshikinuma tarn & $37^{\circ}$ & $39^{\prime}$ & $10^{\prime \prime}$ & $140^{\circ}$ & $5^{\prime}$ & $22^{\prime \prime}$ \\
\hline Lake Hayama & $37^{\circ}$ & $43^{\prime}$ & $42^{\prime \prime}$ & $140^{\circ}$ & $48^{\prime}$ & $27^{\prime \prime}$ \\
\hline Lake Toyanogata & $37^{\circ}$ & $53^{\prime}$ & $49^{\prime \prime}$ & $139^{\circ}$ & $4^{\prime}$ & $1^{\prime \prime}$ \\
\hline Sakata lagoon & $37^{\circ}$ & $49^{\prime}$ & $10^{\prime \prime}$ & $138^{\circ}$ & $52^{\prime}$ & $41^{\prime \prime}$ \\
\hline
\end{tabular}

using the solid polymer electrolyte(SPE) apparatus. Because of the difficulty of measuring the weak $\beta^{-}$radiation (of $\mathrm{T}$ ) and of the low levels of the $\mathrm{T}$ specific activity, it is usually necessary to carry out an isotopic enrichment before measurement ${ }^{1,11), 12}$. In this work, $\mathrm{T}$ in precipitation was measured by liquid scintillation counter (LSC) after both distillation and electrolytic enrichment ${ }^{13)}$.

\section{$2 \cdot 3$ Measurements of activity of $T$ and of} various ions

The samples were distilled to prevent the contaminations of other materials and to minimize quenching ${ }^{14)}$ before electrolytic enrichment. This process was performed by adding both $0.3 \mathrm{~g}$ of $\mathrm{KMnO}_{4}$ and $0.3 \mathrm{~g}$ of $\mathrm{Na}_{2} \mathrm{O}_{2}$ to 1380 $\mathrm{mL}$ of each water sample.

In general, when the $T$ specific activity in an aqueous sample is low $\left(<1 \mathrm{~Bq} \cdot \mathrm{L}^{-1}\right)$, the direct counting of the distilled water using LSC is very difficult, accordingly, the sample needs to be enriched. In the enrichment of $\mathrm{T}$ with electrolysis, a $1080 \mathrm{~mL}$ of sample water is electrolytically concentrated to $36 \mathrm{~mL}$. Consequently, 30 fold of volume enrichment were performed.
In this work, analysis procedure of $\mathrm{T}$ enrichment and the cell design were closely similar to the Masaaki SAITO's description ${ }^{13)}$.

Moreover, major ions $\left(\mathrm{Na}^{+}, \mathrm{K}^{+}, \mathrm{Mg}^{2+}, \mathrm{Ca}^{2+}\right.$, $\mathrm{Cl}^{-}, \mathrm{NO}_{3}{ }^{-}$, and $\mathrm{SO}_{4}{ }^{2-}$ ) in the sample were measured by using both ion chromatography and atomic adsorption spectrometry. In addition, the radioactivities of ${ }^{137} \mathrm{Cs}$ and ${ }^{134} \mathrm{Cs}$ in sediment samples were determined by gamma-ray spectroscopy.

\section{Results and discussions}

\section{$3 \cdot 1 \quad T$ specific activity}

$\mathrm{T}$ specific activity in the precipitation in Niigata City was about $0.6-1.0 \mathrm{~Bq}^{9}$. Fig. 4 shows the activity in the water in each lake. This figure indicates that deposition of $\mathrm{T}$ is easily affected by the topography and may accumulate at the place where convection does not occur. Especially, Lake Akimoto is surrounded by mountains, and it seems that the lake has an almost closed system. Therefore, $\mathrm{T}$ specific activity at Lake Akimoto showed higher value than other samples in Fukushima. In addition, Sakata lagoon in Niigata Prefecture has also closed system, and not connected to Agano 


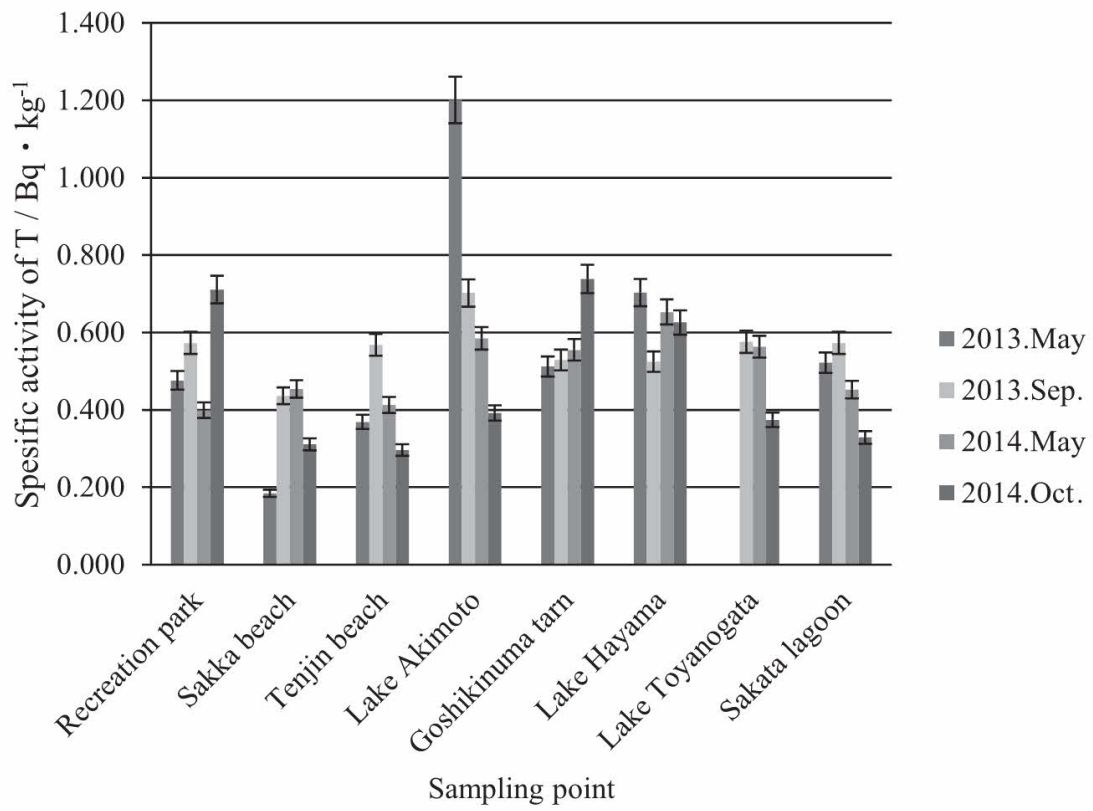

Fig. 4 Specific activity of $\mathrm{T}$ in each lake in Fukushima or Niigata.

river (this rever connected to Fukushima). From our previous research ${ }^{15)}$, it revealed that $\mathrm{T}$ specific activity in Niigata City was increased by the accident. However, this research showed that $\mathrm{T}$ specific activity in Sakata lagoon was not so large, and Sakata lagoon is closed itself. Accordingly, based on T specific activity, effect of the accident on Sakata lagoon could not be observed.

\section{$3 \cdot 2$ Specific activities of ${ }^{134} \mathrm{Cs}$ and ${ }^{137} \mathrm{Cs}$}

Specific activities of ${ }^{134} \mathrm{Cs}$ and ${ }^{137} \mathrm{Cs}$ in the lake sediments were shown in Figs. 5 and 6. From the figures, it is found that the ratio of ${ }^{134} \mathrm{Cs}$ to ${ }^{137} \mathrm{Cs}$ was almost $1: 2$. The Nuclear Power Plant has been worked for a long time. And ${ }^{134} \mathrm{Cs}$ and ${ }^{137} \mathrm{Cs}$ would not be generated in the nuclear reactors after the accident. So, the ratio of ${ }^{134} \mathrm{Cs}$ to ${ }^{137} \mathrm{Cs}$ might be $1: 1$ at the first of the accident. Caesium-134 has a half-life of about 2 years. On the other hand, that of ${ }^{137} \mathrm{Cs}$ is 30 years. When no radioactive material continued to be fallout on these lakes after the accident, the ratio of ${ }^{134} \mathrm{Cs}$ to ${ }^{137} \mathrm{Cs}$ may be estimated almost $1: 2$ after about 2 years. Moreover, we had to consider about influence of aboveground nuclear testing in $1950-1960$ s and Chernobyl disaster. However, these effects can be neglected because the effects were only a few becquerel. Accordingly, it can be deduced that both ${ }^{134} \mathrm{Cs}$ and ${ }^{137} \mathrm{Cs}$ were emitted from the accident, and ${ }^{134} \mathrm{Cs}$ and ${ }^{137} \mathrm{Cs}$ have not discharged since the accident occurred. As to the value of specific activity of each caesium in Lake Inawashiro (see Fig. 2), the activity at outflow place (Recreation Park at Lake Inawashiro) was higher than that at inflow places (Sakka beach at Lake Inawashiro, and Tenjin beach at Lake Inawashiro). The other hand, the influence of the accident to Sakata lagoon in Niigata City could not be found because radioactive caesium could not be observed.

Fig. 7 shows the map of radioactive caeciums on soil in East Japan ${ }^{16}$. From the figure, it 


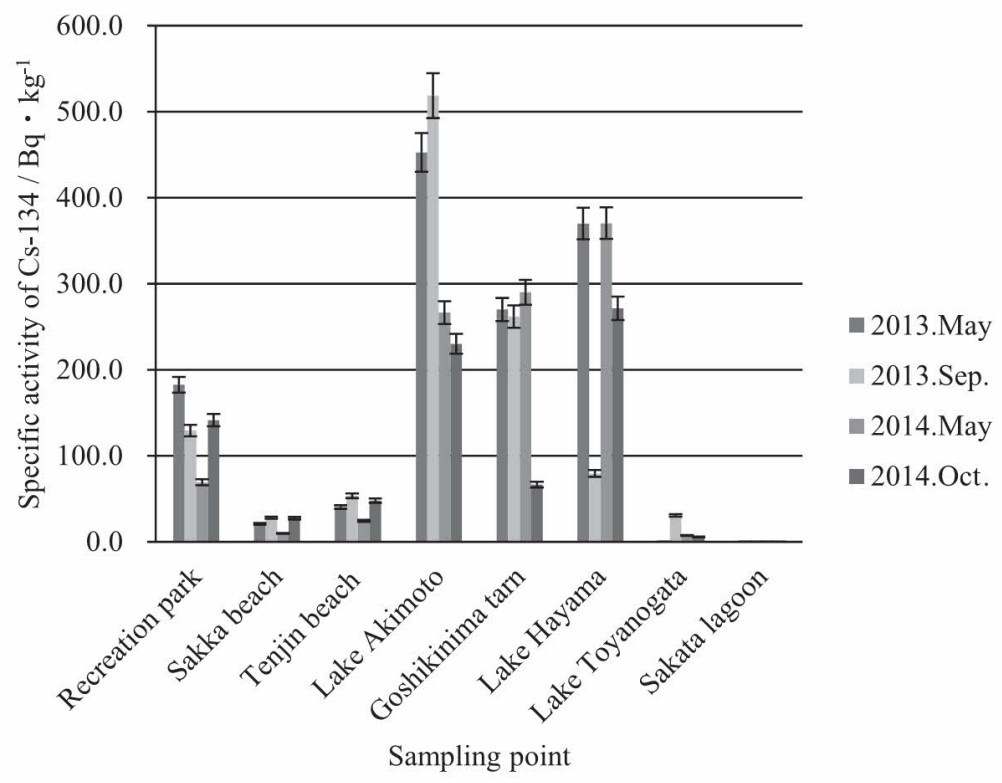

Fig. 5 Specific activity of ${ }^{134} \mathrm{Cs}$ in sediment of each lake in Fukushima or Niigata.

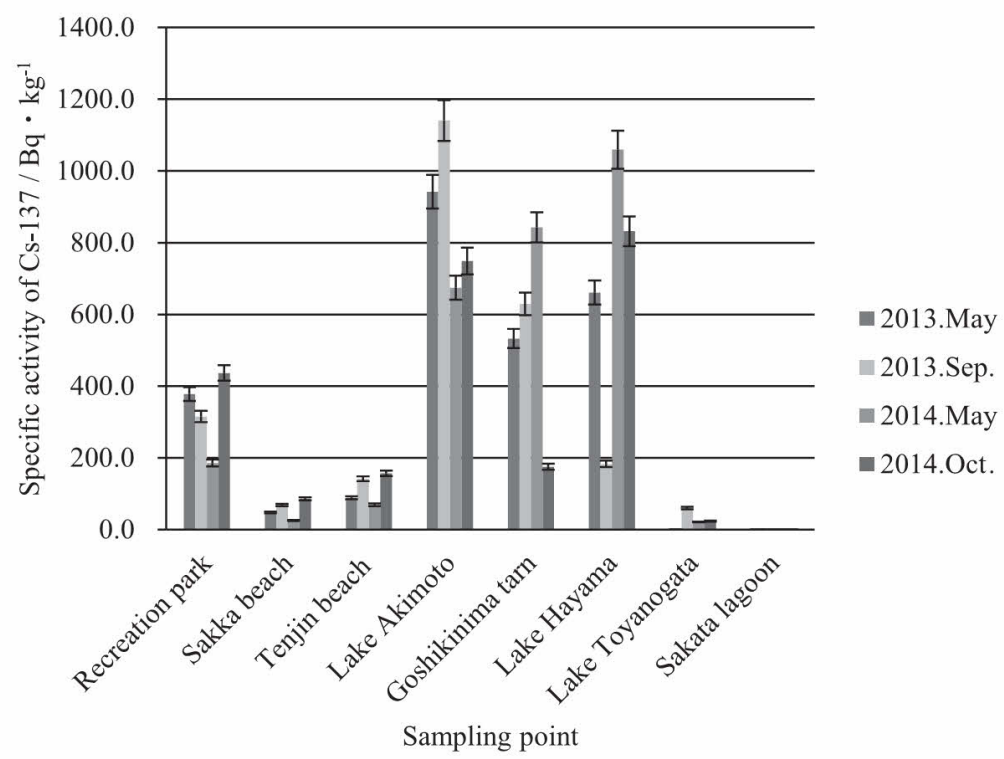

Fig. 6 Specific activity of ${ }^{137} \mathrm{Cs}$ in sediment of each lake in Fukushima or Niigata.

found that east Japan was influenced by the accident directly, especially Fukushima, and adjacent prefectures. In this work, it also seems that the sampling points in Fukushima are influenced by the accident.
On the other hand, in Niigata, the caesium could not be detected in Sakata lagoon. But, the caesium was a little detected in the sediment at Lake Toyanogata. The reason may be that Lake Toyanogata is connected to Agano River, 


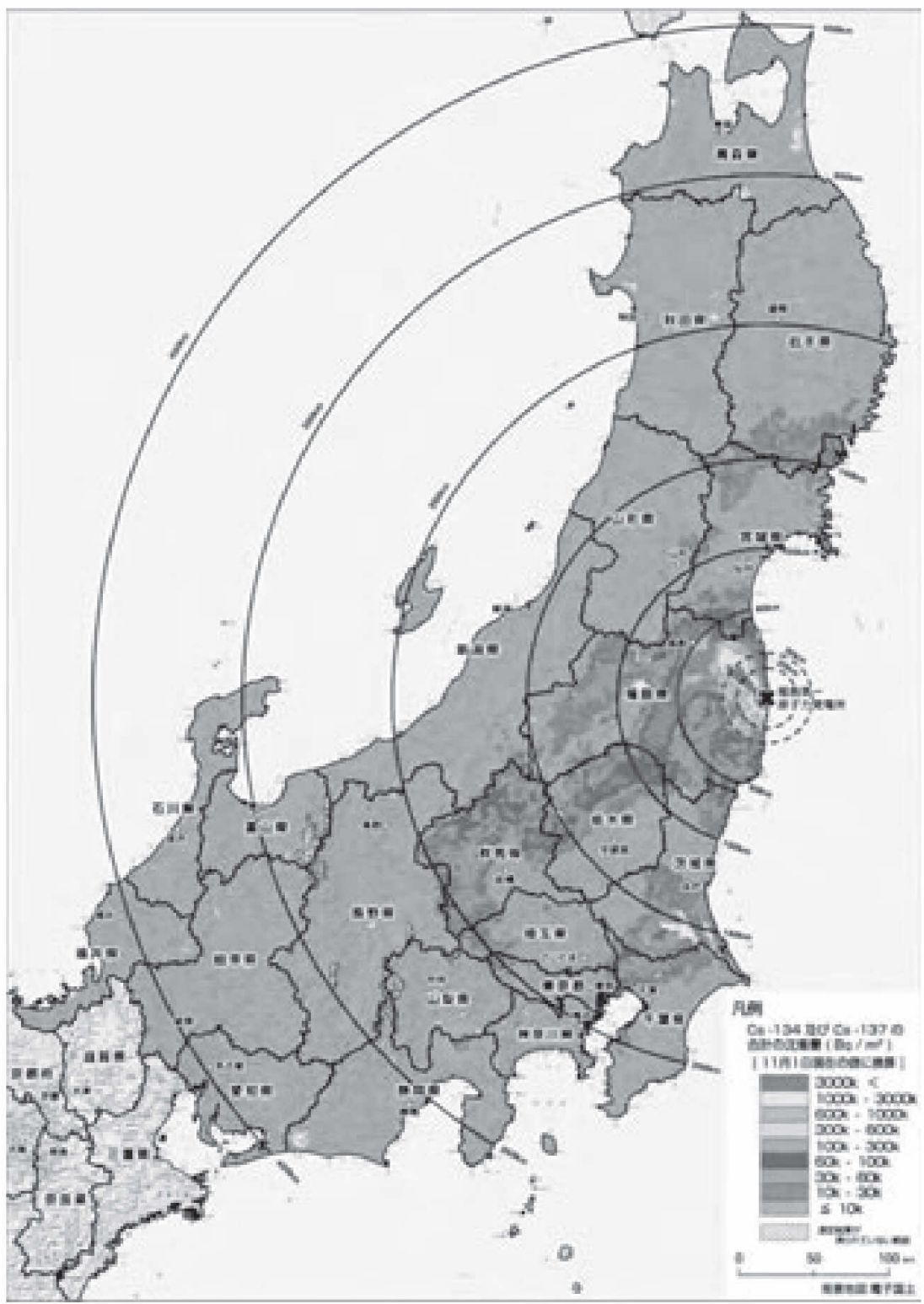

Fig. 7 Map of radioactive caesium on soil in East Japan ${ }^{16)}$.

and the river also connected to Lake Inawashiro through some rivers, consequently, the detected caesium came from Fukushima, especially, Lake Inawashiro.

\section{$3 \cdot 3 \mathrm{DO}, \mathrm{pH}, \mathrm{ORP}$ and various ions}

Dissolved Oxygen (DO), pH, ORP and vari- ous ions in the sample were measured. Do, $\mathrm{pH}$ and ORP in the sample were directly measured at each sampling point (Table 2). There are many hot springs near Goshikinuma tarn. Therefore, the values of these ion concentrations in the sample collected at Goshikinuma tarn were largely different from others, and 
Table 2-1 Several data measured on May $11-12^{\text {th }}$ in $2013(\mathrm{mg} / \mathrm{L})$

\begin{tabular}{lrrrrrrrrrr}
\hline Sampling point & $\begin{array}{l}\mathrm{DO} / \\
\mathrm{mg} \\
\mathrm{L}^{-1}\end{array}$ & $\mathrm{pH}$ & $\begin{array}{c}\mathrm{orp} / \\
\mathrm{mV}\end{array}$ & $\mathrm{Na}^{+}$ & $\mathrm{K}^{+}$ & $\mathrm{Mg}^{2+}$ & $\mathrm{Ca}^{2+}$ & $\mathrm{Cl}^{-}$ & $\mathrm{NO}_{3}^{-}$ & $\mathrm{SO}_{4}{ }^{2-}$ \\
\hline Lake Inawashiro & & & & & & & & & & \\
$\quad$ Recreation park & 9.2 & 7.6 & 209 & 8.89 & 1.82 & 2.40 & 10.8 & 9.83 & 0.74 & 30.9 \\
$\quad$ Sakka beach & 10.3 & 8.0 & 220 & 8.86 & 1.90 & 2.43 & 10.2 & 9.10 & 0.89 & 25.0 \\
$\quad$ Tenjin beach & 9.8 & 7.6 & 206 & 10.9 & 2.27 & 3.27 & 11.4 & 12.1 & 0.81 & 40.8 \\
Lake Akimoto & 9.2 & 8.3 & 243 & 5.75 & 1.27 & 1.28 & 38.4 & 4.49 & 0.66 & 5.71 \\
Goshikinuma tarn & 9.2 & 7.3 & 209 & 65.0 & 10.1 & 20.2 & 71.0 & 58.8 & 0.00 & 247 \\
Lake Hayama & 9.6 & 7.9 & 230 & 6.74 & 1.09 & 2.46 & 10.8 & 4.23 & 0.92 & 3.43 \\
Lake Toyanogata & - & - & - & - & - & - & - & - & - & - \\
Sakata lagoon & 13.5 & 9.8 & 21.0 & 21.0 & 4.58 & 14.9 & 25.5 & 25.8 & 0.23 & 41.2 \\
\hline
\end{tabular}

Table 2-2 Several data measured on Sep. $28-29^{\text {th }}$ in $2013(\mathrm{mg} / \mathrm{L})$

\begin{tabular}{lllllllllll}
\hline Sampling point & $\begin{array}{l}\mathrm{DO} / \\
\mathrm{mg} \\
\mathrm{L}^{-1}\end{array}$ & $\mathrm{pH}$ & $\begin{array}{c}\mathrm{orp} / \\
\mathrm{mV}\end{array}$ & $\mathrm{Na}^{+}$ & $\mathrm{K}^{+}$ & $\mathrm{Mg}^{2+}$ & $\mathrm{Ca}^{2+}$ & $\mathrm{Cl}^{-}$ & $\mathrm{NO}_{3}^{-}$ & $\mathrm{SO}_{4}{ }^{2-}$ \\
\hline Lake Inawashiro & & & & & & & & & & \\
$\quad$ Recreation park & 9.8 & 7.3 & 146 & 9.79 & 1.04 & 2.14 & 7.5 & 9.85 & 0.78 & 31.6 \\
$\quad$ Sakka beach & 8.3 & 8.6 & 156 & 8.67 & 1.02 & 2.12 & 7.8 & 9.72 & 0.91 & 31.5 \\
$\quad$ Tenjin beach & 9.3 & 9.0 & 148 & 9.9 & 1.10 & 2.34 & 8.2 & 10.6 & 0.77 & 31.7 \\
Lake Akimoto & 9.7 & 7.3 & 134 & 55.7 & 5.69 & 0.58 & 57.5 & 58.2 & 0.00 & 254 \\
Goshikinuma tarn & 7.9 & 7.0 & 156 & 5.7 & 0.7 & 0.8 & 3.2 & 6.0 & 0.00 & 6.0 \\
Lake Hayama & 7.9 & 7.6 & 155 & 5.75 & 0.52 & 1.77 & 8.2 & 3.91 & 0.73 & 3.42 \\
Lake Toyanogata & 6.5 & 6.4 & 72 & 74.6 & 3.0 & 10.7 & 15.3 & 13.6 & 1.8 & 31.6 \\
Sakata lagoon & 11.8 & 6.5 & 121 & - & 2.97 & 9.8 & 27.8 & 49.5 & 0.00 & 22.1 \\
\hline
\end{tabular}

the concentrations of the ions may be influenced by hot spring. In addition, the value of $\mathrm{pH}$ in Sakata lagoon was larger than others because there were a lot of plants in the lagoon at the sampling day and the water sampled was so muddy.

$3 \cdot 4$ Comparing the caesium in the samples with each other

The samples were also collected in autumn
(Sep., 2013 and Oct., 2014). Base on Figs. 5 and 6 , comparing the specific activity of ${ }^{137} \mathrm{Cs}$ at spring sample with autumn one, it is found that the specific activity of ${ }^{137} \mathrm{Cs}$ was increased at closed-system place (Lake Akimoto) and at outflow ones (Sakka beach and Tenjin beach at Lake Inawashiro (see Fig. 2)). However, the activities at Lake Hayama were low (Sep., 2013). The reason is that water level at Lake Hayama was much higher than the level at the day sam- 
Table 2-3 Several data measured on May $30-31^{\text {th }}$ in $2014(\mathrm{mg} / \mathrm{L})$

\begin{tabular}{|c|c|c|c|c|c|c|c|c|c|c|}
\hline Sampling point & $\begin{array}{l}\mathrm{DO} / \\
\mathrm{mg} \\
\mathrm{L}^{-1}\end{array}$ & $\mathrm{pH}$ & $\begin{array}{l}\text { orp / } \\
\mathrm{mV}\end{array}$ & $\mathrm{Na}^{+}$ & $\mathrm{K}^{+}$ & $\mathrm{Mg}^{2+}$ & $\mathrm{Ca}^{2+}$ & $\mathrm{Cl}^{-}$ & $\mathrm{NO}^{3-}$ & $\mathrm{SO}_{4}{ }^{2-}$ \\
\hline \multicolumn{11}{|l|}{ Lake Inawashiro } \\
\hline Recreation park & 9.1 & 7.8 & 557 & 8.39 & 2.03 & 2.38 & 7.6 & 11.1 & 0.73 & 32.3 \\
\hline Sakka beach & 10.5 & 7.5 & 492 & 8.04 & 1.92 & 2.31 & 8.2 & 10.8 & 1.10 & 32.2 \\
\hline Tenjin beach & 9.5 & 6.9 & 420 & 8.4 & 2.21 & 2.51 & 8.8 & 11.4 & 1.12 & 36.6 \\
\hline Lake Akimoto & 8.0 & 7.3 & 398 & 2.89 & 0.87 & 0.81 & 3.6 & 3.22 & 1.47 & 4.82 \\
\hline Goshikinuma tarn & 8.0 & 6.6 & 212 & 39.7 & 7.3 & 13.9 & 57.3 & 46.5 & 0.13 & 216 \\
\hline Lake Hayama & 10.3 & 8.4 & 268 & 4.64 & 0.71 & 1.85 & 4.5 & 4.37 & 1.09 & 3.16 \\
\hline Lake Toyanogata & 7.0 & 8.1 & 92 & 74.3 & 4.04 & 9.42 & 10.2 & 161 & 3.68 & 21.8 \\
\hline Sakata lagoon & 11.0 & 8.2 & 591 & 20.2 & 4.78 & 13.2 & 26.4 & 25.8 & 6.18 & 33.2 \\
\hline
\end{tabular}

Table 2-4 Several data measured on Oct. $9-10^{\text {th }}$ in $2014(\mathrm{mg} / \mathrm{L})$

\begin{tabular}{|c|c|c|c|c|c|c|c|c|c|c|}
\hline Samp & $\begin{array}{l}\mathrm{DO} / \\
\mathrm{mg} \\
\mathrm{L}^{-1}\end{array}$ & $\mathrm{pH}$ & $\begin{array}{l}\text { orp / } \\
\mathrm{mV}\end{array}$ & $\mathrm{Na}^{+}$ & $\mathrm{K}^{+}$ & $\mathrm{Mg}^{2+}$ & $\mathrm{Ca}^{2+}$ & $\mathrm{Cl}^{-}$ & $\mathrm{NO}_{3}^{-}$ & $\mathrm{SO}_{4}^{2-}$ \\
\hline \multicolumn{11}{|l|}{ Lake Inawashiro } \\
\hline Recreation park & 9.7 & 6.8 & 130 & 7.76 & 1.89 & 2.25 & 7.9 & 10.3 & 0.51 & 31.2 \\
\hline Sakka beach & 9.0 & 7.5 & 202 & 7.99 & 1.97 & 2.34 & 77.0 & 10.6 & 0.60 & 32.1 \\
\hline Tenjin beach & 12.0 & 7.2 & 163 & 11.8 & 3.66 & 3.31 & 11.4 & 15.3 & 0.16 & 34.7 \\
\hline Lake Akimoto & 10.0 & 7.4 & 216 & 5.43 & 1.89 & 1.02 & 4.3 & 5.73 & 0.00 & 6.34 \\
\hline Goshikinuma tarn & 8.1 & 6.6 & 199 & 48.2 & 8.4 & 15.6 & 58.3 & 59.5 & 0.12 & 227 \\
\hline Lake Hayama & 9.6 & 7.7 & 244 & 5.65 & 0.95 & 2.04 & 5.3 & 4.34 & 0.26 & 3.75 \\
\hline Lake Toyanogata & 4.5 & 6.7 & 166 & 46.3 & 6.27 & 7.09 & 38.4 & 68.2 & 6.68 & 14.2 \\
\hline Sakata lagoon & 11.3 & 7.9 & 221 & 20.4 & 6.25 & 1.0 & 19.4 & 32.3 & 0.00 & 41.4 \\
\hline
\end{tabular}

pled (comparing with the sampling days (May, 2013, May, 2014, and Oct., 2014) ),therefore, we could not sample at the same place.

\section{Conclusions}

In order to reveal the effect of the Fukushima Daiichi Nuclear Power Plant Accident on some lakes in Fukushima and Niigata, the lake waters and sediments were collected and measured. From the result, the following conclusions are clarified.

(1) The effect of the accident on several lakes was clarified because the ratio of ${ }^{134} \mathrm{Cs}$ to ${ }^{137} \mathrm{Cs}$ was almost $1: 2$ after about 2 years. As to the lakes, specific activities of the caesium at outflow place apt to be higher than in inflow places.

(2) The deposition of each caesium was greatly affected by the topography and it seems that each caesium was deposited in 
closed-system place.

(3) The measurement results show the T specific activity was similar to that of the precipitation recently collected at Niigata City. Therefore, based on T specific activity, the effect of the nuclear accident may be no longer observed in Niigata City after 5 months.

(4) It seems that if the lake does not circulate, $T$ cannot move, and be accumulated there.

\section{References}

1) Jiao, Y., Imaizumi, H. and Kano, N., Journal of Environmental Science and Engineering A, 1, 1218-1225 (2012)

2) Matsumoto, T., Maruoka, T., Shimoda, G. et al., Science of Total Environment, 445-446, 365-370 (2013)

3) Hisamatsu, S. and Takizawa, Y., J. Radioanal. Nucl. Chem., 197, 271-280(1995)

4) Hisamatsu, S., Amano, H., Isogai, K., Atarashi, M., Zhu, H. and Takizawa, Y., Health Phys., 74, 448450 (1998)

5) Hisamatsu, S., Amano, H., Isogai, K., Atarashi, M.,
Zhu, H. and Takizawa, Y., Atmos. Environ., 27, 293246 (1993)

6) Rozanski, K., Gonfiantini, R. and Araguas-Araguas, L., J. Phys. G : Nucl. Part. Phys., 17, S523-S 536(1991)

7) Akata, N., Kakiuchi, H., Shima, N., Iyogi, T., Momoshima, N. and Hisamatsu, S., Journal of Environmental Radioactivity, 102, 837-842(2011)

8) Rundo, J., Journal of Radiology, 37, 108-114 (1964)

9) Takahashi, Y., Imaizumi, H., Kano, N., Saito, M., Kato, N., Ishii, Y. and Saito K., RADIOISOTOPES,

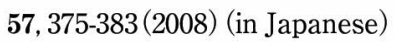

10) Ishii, Y., Saito, M., Imaizumi, H., Kato, N. and Kitaoka, K., RADIOISOTOPES, 63, 79-86(2014) (in Japanese)

11) Kaufman, S. and Libby, W, F., Phys., 93, 1337-1344 (1954)

12) Washburn, E. W. and Urey, H. C., Proc. Natn. Acad.Sci. U.S.A., 18, 496-498(1932)

13) Saito, M., Takata, S., Shimamune, T., Nishiki, Y., Shimizu, H. and Hayashi, T., RADIOISOTOPES, 45, 285-292 (1996) (in Japanese)

14) Metson, B. P., Analyst, 94, 1122-1129(1969)

15) Kataoka, N., Imaizumi, H. and Kano, N., Nucl Science Tech., 49, 667-672(2012)

16) http://purple.noblog.net/blog/q/11257781.html 
要旨

\title{
福島県と新潟市の湖沼に及ぼす福島第一原子力発電所事故の影響
}

\author{
神田直之, 王 禜, 片岡憲昭, 山田龍太, 今泉 洋 ${ }^{\dagger}$, 狩野直樹 \\ 新潟大学工学部化学システム工学科 \\ 950-2181 新潟県新潟市西区五十嵐二の町 8050 \\ †analysis@eng.niigata-u.ac.jp \\ 2015 年 4 月 20 日 受付 \\ 2015 年 9 月 8 日 受理
}

2011 年 3 月 $12 \sim 15$ 日に, 福島第一原子力発電所事故が起こった。この事故は, 近県に放射性 物質污染を引き起こした。本研究では，污染された地域に及ぼすこの事故の影響を明らかにするた め, 新潟市と福島県に扔ける幾つかの湖沼の湖沼水と湖沼泥を採取した。湖沼水に抢いては, 固体 高分子膜電解（SPE）装置によりトリチウム (T) 比放射能の濃縮を行い, T-比放射能を液シンで 測定した。このように測定した T-比放射能に基づき，環境に及ほすこの事故の影響を調査した。 それと同時に, 湖沼泥中の放射性セシウムの比放射能も測定した。その結果, 福島第一原子力発電 所事故が近くの湖沼（例えば，福島県や新潟市）に及ぼす影響が定量的に明らかになった。以上の ことから, 新潟市に及ぼすこの事故の影響はかなり小さく, 事故は徐々に収束していることがわか った。 